\title{
Spatial distributions of groundfish in the northern Bering Sea in relation to environmental variation
}

\author{
Xuehua Cui ${ }^{1, *}$, Jacqueline M. Grebmeier ${ }^{2}$, Lee W. Cooper ${ }^{2}$, James R. Lovvorn ${ }^{3}$, \\ Christopher A. North ${ }^{4}$, William L. Seaver ${ }^{5}$, Jason M. Kolts ${ }^{4}$ \\ ${ }^{1}$ Department of Ecology and Evolutionary Biology, University of Tennessee, 569 Dabney Hall, 1416 Circle Drive, Knoxville, \\ Tennessee 37996, USA \\ ${ }^{2}$ Chesapeake Biological Laboratory, University of Maryland Center for Environmental Science, 1 Williams Street, PO Box 38, \\ Solomons, Maryland 20688, USA \\ ${ }^{3}$ Department of Zoology and Center for Ecology, Southern Illinois University, 1125 Lincoln Drive, MC6501, Carbondale, \\ Illinois 62901, USA \\ ${ }^{4}$ Department of Zoology and Physiology and Program in Ecology, University of Wyoming, 1000 E University Avenue, \\ Laramie, Wyoming 82071, USA
}

${ }^{5}$ Department of Statistics, Operation, and Management Science, University of Tennessee, 331 SMC, 916 Volunteer Boulevard, Knoxville, Tennessee 37996, USA

\begin{abstract}
Two bottom trawl surveys of fish were undertaken during the seasonal sea ice retreat in 2006 and 2007 in the northern Bering Sea. For each trawl, we calculated catch per unit area (CPUA) for all fish taxa. Arctic cod Boreogadus saida, Bering flounder Hippoglossoides robustus and snailfish (Liparidae) were the dominant species south of St. Lawrence Island (SLI), whereas Arctic alligatorfish Ulcina olrikii, Arctic staghorn sculpin Gymnocanthus tricuspis and shorthorn sculpin Myoxocephalus scorpius were the dominant fishes north of SLI. Cluster analysis and multidimensional scaling were used to investigate relationships between environmental conditions and fish community structure in the northern Bering Sea. One goal of the study was to assess the importance of environmental variables on groundfish assemblages. The results showed that sediment grain size (an indicator of current speed) was the most important environmental factor explaining fish community structure in both years of the study. Bottom water nutrients (nitrate + nitrite), bottom water chlorophyll a (chl a) (with similar results for total chl $a$ in the water column), sediment grain size, and sediment $\mathrm{C} / \mathrm{N}$ ratios had stronger relationships with fish distribution in 2006 (cold, pre-bloom conditions), whereas bottom water temperature and sediment grain size were more important in 2007 (warm, bloom conditions) among a total of 14 environmental variables that were analyzed. These findings indicate strong linkages between physical conditions (e.g. water temperature and hydrography as it affects sediment grain size) and biological conditions (e.g. bloom status) in structuring fish communities in the northern Bering Sea.
\end{abstract}

KEY WORDS: Northern Bering Sea $\cdot$ Groundfish $\cdot$ Environmental factors $\cdot$ Fish distribution $\cdot$ Cluster analysis · Arctic cod

\section{INTRODUCTION}

The Bering Sea shelf is one of the most biologically productive regions in the sub-Arctic seas and supports large populations of fishes, crabs, marine mammals and seabirds (Loughlin et al. 1999). This productivity includes extensive commercial fisheries in the south- eastern Bering Sea (Aydin \& Mueter 2007). By contrast, in the northern Bering Sea, commercial fisheries are currently absent, but the system is no less productive. Nutrient-rich Anadyr water moves along the western side of the northern shelf through the Gulf of Anadyr and provides a continuous source of nutrients for high primary production in the western regions of the 
northern Bering and Chukchi seas (Springer et al. 1996, Grebmeier \& Barry 2007). High nutrient water also moves northward from the southern Bering Sea shelf during the winter onto the northern shelf until seasonal water masses form in the spring (Danielson et al. 2006). This includes a branch of the Anadyr Current that flows west to east south of St. Lawrence Island (SLI) during the ice-free summer (Walsh et al. 1989, Nihoul et al. 1993, Grebmeier \& Cooper 1995, Clement et al. 2005, Danielson et al. 2006, Grebmeier \& Barry 2007). Summer primary production becomes more limited in the region after nutrient depletion from the spring bloom.

Evidence is accumulating that the Bering Sea is undergoing a northward biogeographical shift as a result of atmospheric and hydrographic forcing that may be climate-related (Overland \& Stabeno 2004, Grebmeier et al. 2006, Bluhm \& Gradinger 2008, Mueter \& Litzow 2008). Environmental change over the last decade in the Arctic has been dramatic, and the most obvious evidence has been the reduced extent and earlier melting of seasonal pack ice (Serreze et al. 2007). Increases in ocean and atmosphere temperatures and lower sea-ice concentrations and duration strongly affect Arctic biological communities (Grebmeier et al. 2006). Near-freezing $\left(<0^{\circ} \mathrm{C}\right)$ bottom water south of SLI in summer (a 'cold pool' resulting from winter sea ice production) limits the numbers and growth of groundfish (Wyllie-Echeverria \& Wooster 1998, Grebmeier et al. 2006). Expansion of fish populations as seasonal sea ice cover declines and the cold pool shrinks may affect food availability for other apex predators and may also affect commercial and subsistence fishery harvests in the sub-Arctic (Grebmeier et al. 2006). Despite these potentially important ecological changes, the spatial distribution of benthic fish communities and how they are affected by the physical environment are not well known in the northern Bering Sea. Many past fisheries research programs have focused on single species that are commercially important rather than multi-species communities, and even community level studies have been undertaken primarily in the southeastern Bering Sea or Gulf of Alaska where commercial fisheries are most prominent (e.g. Brodeur et al. 1999, Mueter \& Norcross 2002, Aydin \& Mueter 2007, Mueter \& Litzow 2008). Therefore, to anticipate fish distribution shifts with changing climate and thereby aid in the management of Bering Sea fisheries, a better understanding is needed of benthic fish communities on the northern shelf.

Within this context, the goals of the present study were to (1) describe the spatial pattern of demersal fish communities in the northern Bering Sea and (2) identify the main environmental factors influencing groundfish communities using multivariate approaches.

\section{MATERIALS AND METHODS}

Fish sampling. We sampled groundfish in the northern Bering Sea around SLI (Fig. 1) during 2 cruises on the USCGC 'Healy' from 7 May to 5 June 2006 (HLY0601), and from 16 May to 18 June 2007

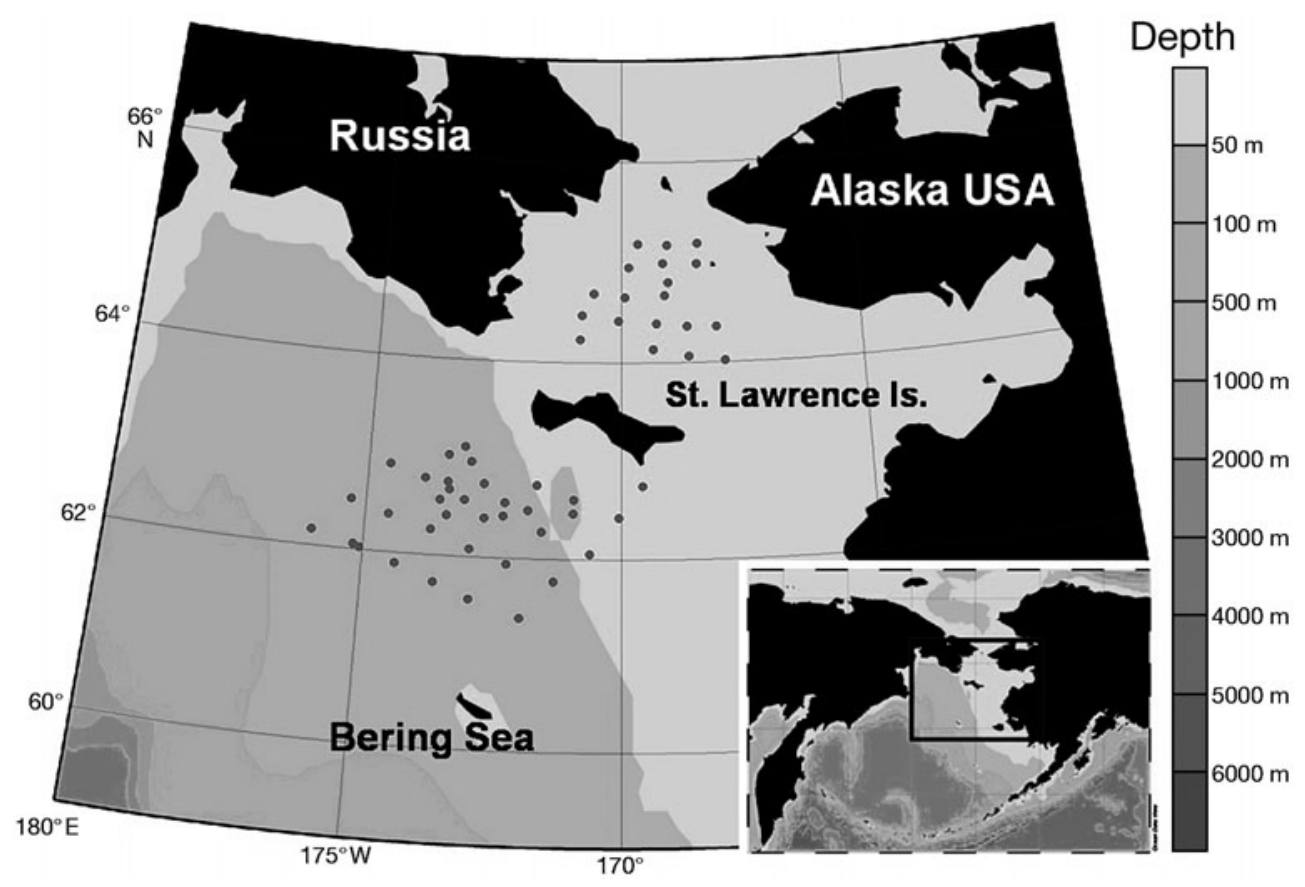

Fig. 1. Study area in the northern Bering Sea and station locations in 2006 and 2007 with bathymetry indicated 
(HLY0702). In 2006, we sampled groundfish using an otter trawl $(4.3 \mathrm{~m}$ long, $1.9 \mathrm{~cm}$ stretched mesh, $3.43 \mathrm{~m}$ wide opening) at 43 stations ( 60 hauls). In 2007, a beam trawl $(4.3 \mathrm{~m}$ long, $1.9 \mathrm{~cm}$ stretched mesh, $4 \mathrm{~m}$ wide opening) was used at 52 stations (63 hauls), with replicate otter trawls undertaken at 14 stations to allow comparison of the catch efficiency of the 2 different sampling nets. All trawls were deployed at a speed of $\sim 2$ knots for durations on the bottom of 5 to $30 \mathrm{~min}$ in 2006 and 2 to $25 \mathrm{~min}$ in 2007 . The shorter time durations were used in muddy sediments with high abundances of brittle stars that otherwise would overwhelm the net in a few minutes. These considerations were used in adjusting trawl bottom time according to expected trawl load, and based on previous trawling efforts (J. M. Grebmeier, unpubl. data). To test for possible biases associated with short trawls, 6 stations were sampled in 2007 with trawl bottom times of $<5$ min were re-sampled with longer bottom times of 5 to $24 \mathrm{~min}$. No obvious differences in fish communities were detected between samples of differing trawl duration at the same stations.

Fish were sorted and identified to species or to the lowest possible taxon using the keys of Mecklenburg et al. (2002). All fish were measured for total length ( $\mathrm{TL}, \pm 1 \mathrm{~mm}$ ), and total mass ( $\mathrm{TM}, \pm 1 \mathrm{~g}$ ).

Data standardization. Frequency of occurrence (FO) was calculated for each taxon, indicating the probability of capturing a given taxon in a sampling area. The catch per unit area (CPUA) of each species was expressed as both number of fish $\mathrm{km}^{-2}$ and biomass $(\mathrm{kg})$ of fish $\mathrm{km}^{-2}$. Area swept by the net was computed as the effective width of the net opening (otter trawl, $3.43 \mathrm{~m}$; beam trawl, $4 \mathrm{~m}$ ) multiplied by the distance towed on the bottom. In 2007, distances towed on the bottom were calculated for the beam and otter trawls by means of a shipboard GPS and a trawl-mounted depth logger (Sensus Ultra, ReefNet) that allowed us to determine the precise period the trawls were on the bottom. In 2006 when depth loggers were not deployed, we estimated the trawling time on the bottom using regression analyses of the relationship between cable payout length, depth and heading from the 2007 data sets when depth loggers were deployed, and then calculated distance traveled over the estimated time period using shipboard GPS data. All bottom trawl distances were corrected for trawl movement relative to ship movement by means of electronically recorded winch data. Specifically, we employed a correction formula with the length of payout cable (m) when the net first reached the bottom set equal to $[(2.073 \times$ depth $)+11.2]$ for stations south of SLI, and $[(2.420 \times$ depth $)-(0.272 \times$ southing $)+22.1]$ for stations north of SLI, where southing $=$ |heading $-180^{\circ}$ । (C. A. North, unpubl. data).
To examine changes in CPUA for abundance and biomass in the $2 \mathrm{yr}$, we used regression models to convert otter trawl CPUA in 2006 to comparable beam trawl CPUA with 14 station replicates. For CPUA in terms of fish abundance, 2 stations with weight $=0.00$ (VNG4) and 0.25 (SEC2) were treated as an outlier and partial outlier, respectively, with the remaining 12 stations having weights from 0.77 to 1.00 assigned by Andrew's sine robust linear regression model as determined by Number Cruncher Statistical System (NCSS) software (2007, Hintze 2009; Fig. 2a). The resulting relationship between beam $(B)$ and otter $(O)$ trawls was $B=-74.830+0.202 \times O\left(\mathrm{r}^{2}=0.85\right)$. For CPUA in terms of biomass, 1 outlier (Stn RUSA) was eliminated. The relationship was best described by a nonlinear regression $B=0.006800 \times O+0.000163 \times O^{2}\left(r^{2}=0.92\right)$ (Fig. 2b). In both outlier stations VNG4 and RUSA, trawl time was 2 to $3 \mathrm{~min}$, which might have caused the variance in the sampling results. We used these regressions to convert otter trawl data in 2006 to equivalent beam trawl data. The regression model for fish abundance is more reliable than the model for fish biomass because the data are more evenly distributed across the range of values. However, in beam trawl data from 2007, fish assemblages identified in terms of abundance showed no large differences from those identified in terms of biomass.
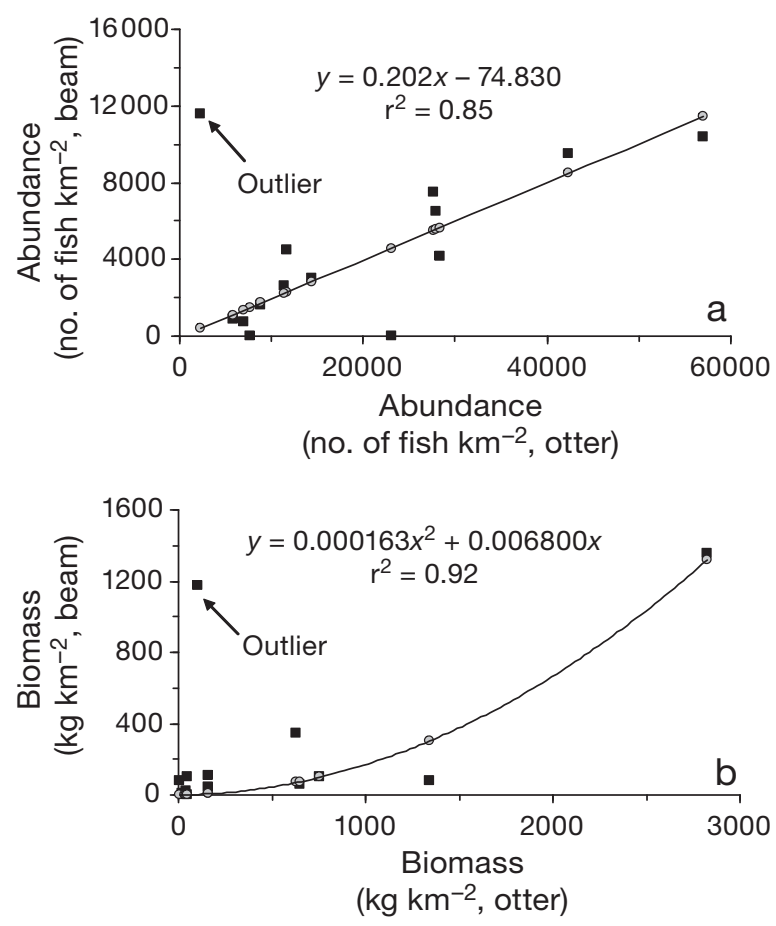

Fig. 2. Graph showing the observed ( $\square$ ) and predicted (o) values of (a) abundance and (b) biomass catch per unit area based upon regression analysis used to facilitate comparisons between the 2 trawl methods (see 'Data standardization' in 'Materials and methods') 
Environmental data. Fourteen environmental variables were measured at each trawl station: (1) depth $(\mathrm{m}),(2)$ bottom water temperature $\left({ }^{\circ} \mathrm{C}\right)$, (3) bottom water salinity, (4) bottom water silica $\left(\mu \mathrm{mol} \mathrm{l}^{-1}\right)$, (5) bottom water nitrite and nitrate $\left(\mu \mathrm{mol} \mathrm{l^{-1 }}\right)$, (6) bottom water phosphate $\left(\mu \mathrm{mol} \mathrm{l^{-1 }}\right),(7)$ bottom water ammonium ( $\left.\mathrm{mmol} \mathrm{l}^{-1}\right)$, (8) bottom water chlorophyll a (chl $a_{\text {, }}$ $\left.\mathrm{mg} \mathrm{m}^{-3}\right)$, (9) integrated water column chl $a\left(\mathrm{mg} \mathrm{m}^{-2}\right)$, (10) $\mathrm{chl} a$ in surface sediments $\left(\mathrm{mg} \mathrm{m}^{-2}\right),(11)$ surface sediment grain size (phi), (12) total organic carbon of surface sediments (TOC, \%), (13) total organic nitrogen of surface sediments (TON, \%), and (14) surface sediments $\mathrm{C} / \mathrm{N}$ (wt/wt). Bottom water was collected from 0 to $5 \mathrm{~m}$ above the bottom.

The 14 hydrographic and sediment parameters were measured as follows. Depth, temperature and salinity were measured by sensors mounted on a CTD profiler. Water samples for inorganic nutrients (items 4 to 7 above) were collected from the rosette of bottles on the CTD. These samples were frozen upon collection and analyzed at the Marine Science Institute at the University of California, Santa Barbara, by means of a nutrient autoanalyzer. For chlorophyll determinations, additional seawater samples $(250 \mathrm{ml})$ were collected at up to 12 depths from the same rosette, filtered using Whatman $\mathrm{GF} / \mathrm{F}$ filters, and extracted in $90 \%$ acetone for $24 \mathrm{~h}$ at $4^{\circ} \mathrm{C}$ in the dark. At the end of this incubation period, chl a concentrations in the water column were measured with a Turner Designs AU-10 fluorometer without acidification (see Cooper et al. 2002, Clement et al. 2004 for detailed methods). For measurements of sediment chl $a_{\text {, }}$ duplicate $1 \mathrm{~cm}^{3}$ samples of surface sediments were collected from the top of a van Veen grab at each station. After adding $10 \mathrm{ml}$ of $90 \%$ acetone to each sediment sample, samples were stored for $12 \mathrm{~h}$ at $4^{\circ} \mathrm{C}$ in the dark, and the chl a concentration was measured using the same fluorometer (Cooper et al. 2002, Clement et al. 2004). Samples for sediment grain size and total organic carbon and nitrogen in sediments were collected from the top centimeter of HAPS benthic cores collected at each station (Grebmeier et al. 1989). Sediment subsamples $(1 \mathrm{~g})$ were acidified with $2 \mathrm{ml}$ of $1 \mathrm{~N} \mathrm{HCl}$ and dried at $105^{\circ} \mathrm{C}$ overnight before measurements of TOC and TON were made on a CHN analyzer (Exeter Analytical model 240XA). Samples for sediment grain size were dried, homogenized, chemically processed to remove organics and sieved using standard geological sieves (0 to $4 \mathrm{Phi}$ mesh size). Sediments were weighed after sieving and percent composition and modal sediment size calculated (for further details see Pirtle-Levy 2006).

Fish community and habitat relationships. Cluster analysis and multidimensional scaling (MDS) were used to distinguish groundfish assemblages and spatial distributions. These methods were conducted with the statistical software PRIMER (v. 6, Plymouth Routines in
Ecological Research, available at: www.primer-e.com). Reoccupied stations in each year were treated as independent samples. A few fish species that occurred at $<5 \%$ of stations were excluded from cluster analysis (following Gauch 1982, Clarke \& Warwick 2001). We grouped fish species and stations according to fish abundance, and used hierarchical clustering with group-average linking of Bray-Curtis similarities on $\log (x+1)$ transformed benthic fish abundance data (Clarke \& Warwick 2001). Log-transformation was used to reduce the influence of dominant species. The dominant fish species and environmental factors in cluster groups were compared for significant differences using a 2-sample Hotelling's T2 randomization test based on 10000 Monte Carlo samples using NCSS 2007 software (Hintze 2009). The randomization test is conducted by enumerating all possible permutations of the sample data, calculating the statistic test for each permutation and counting the number of permutations with a T2 value equal to or greater than the actual T2 value (Hintze 2009). Dividing this count by the number of permutations tried provides the significance level of the test (Hintze 2009). This 2 -sample Hotelling's T2 test is a multivariate version of a 2-sample $t$-test, and a randomization test does not rely on assumptions such as random samples and normal distribution (Hintze 2009).

The BIO-ENV procedure in PRIMER was used to link environmental variables to fish community structure, including estimates of how well environmental characteristics explained fish distributions. This procedure handles separately biotic and abiotic data, constructs sample (dis)similarity matrices, such as Bray-Curtis for biota and Euclidean distance for abiotic variables, and chooses an abiotic variable subset to maximize rank correlation ( $\rho$ ) between biotic and abiotic (dis)similarity matrices (Clarke \& Warwick 2001). Log-transformed data $\log (x+1)$ were used for all biotic and abiotic variables (Clarke \& Warwick 2001). In other words, rank was compared through the Spearman coefficient $(\rho)$, which has the range ( -1 to 1$)$ with the extremes of $\rho$, -1 and +1 , corresponding to cases where the 2 sets of ranks are in complete opposition or complete agreement, respectively.

Map of stations, spatial pattern of environmental factors, and groundfish abundances in 2006 and 2007 were created using Ocean Data View (ODV, v. 1.4; Schlitzer 2003).

\section{RESULTS}

\section{Environmental conditions in trawl survey stations}

During sampling in May and June, ice cover was lower in 2007 than in 2006 (Fig. 3). The depth range of trawl deployments was 35 to $96 \mathrm{~m}$. Bottom water temperatures 


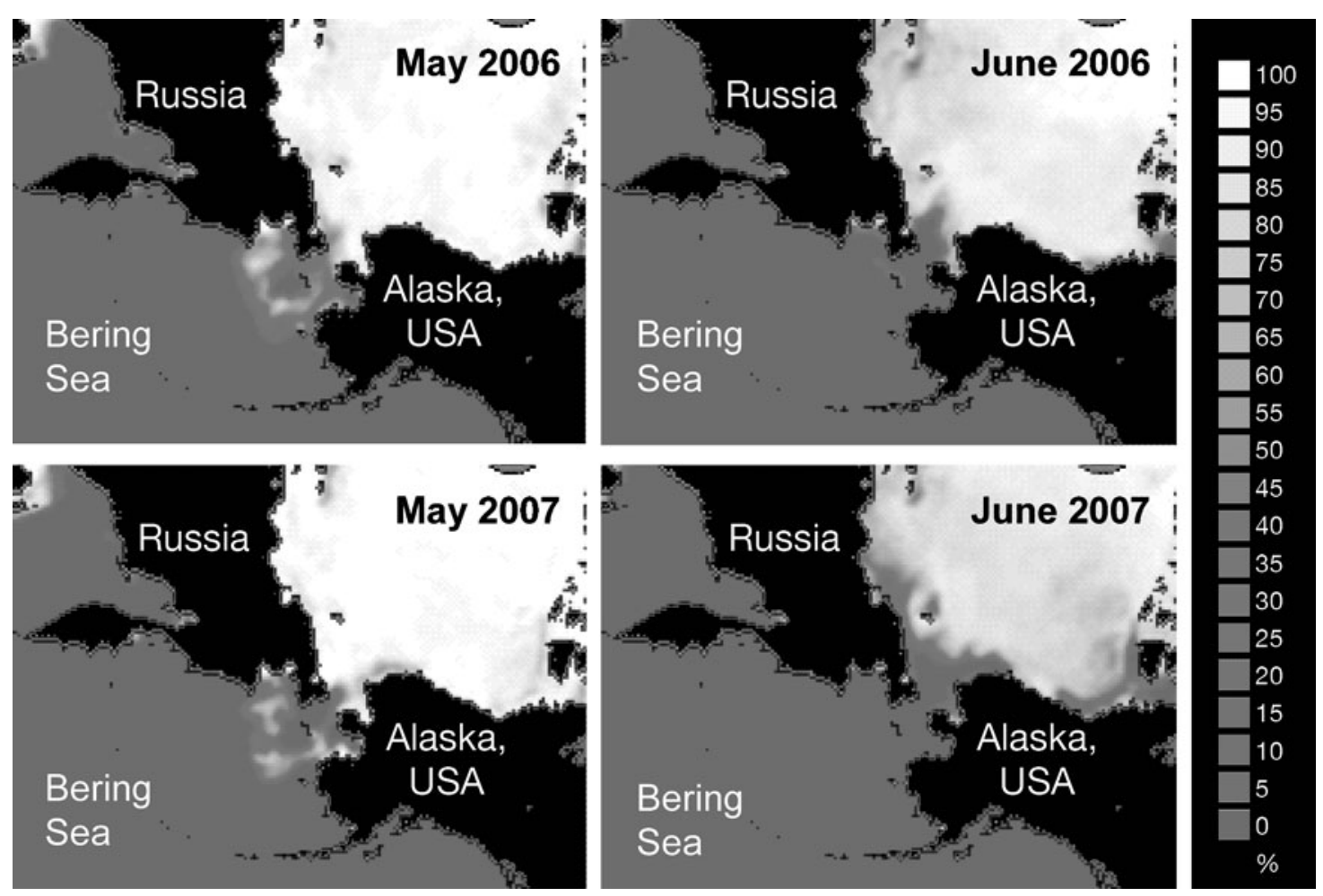

Fig. 3. Sea ice concentration in May and June 2006 and 2007 (images edited from the Sea Ice Index; Fetterer et al. 2008)

at most trawl survey stations were from -1.8 to $-1.4^{\circ} \mathrm{C}$ south of SLI in both 2006 and 2007, reflecting the presence of a cold pool generated by ice formation in the winter polynya south of SLI (Fig. S1a available as Supplementary Material at www.int-res.com/articles/suppl/ m393p147_app.pdf). Warmer bottom water temperatures occurred north of SLI, particularly in 2007 ( -0.4 to $\left.0.6^{\circ} \mathrm{C}\right)$. Mean $( \pm \mathrm{SD})$ bottom water salinity was higher in $2007(32.7 \pm 0.2)$ than in 2006 (32.1 \pm 0.3$)$ (Fig. S1b). Integrated water column chl a was lower (10 to $100 \mathrm{mg} \mathrm{m}^{-2}$ ) in 2006 at stations to the southeast and farthest south of SLI, and higher (300 to $800 \mathrm{mg} \mathrm{m}^{-2}$ ) in most of the remaining stations (Fig. S1c). In 2007, the highest chl a concentrations integrated over the water column (700 to $1000 \mathrm{mg} \mathrm{m}^{-2}$ ) were observed from northeast of SLI extending toward the Bering Strait, with lower concentrations (100 to $500 \mathrm{mg} \mathrm{m}^{-2}$ ) observed elsewhere. Organic matter (TOC and TON) in surface sediments was highest to the southwest of SLI in both years (Fig. S1d). Sediment grain size, an indicator of current speed, generally was finer south of SLI and coarser north of SLI, with gravel close to the Bering Strait (Fig. S1e).

\section{Comparison of otter and beam trawls}

Differences in the sizes of fish caught by the 2 different gear types were tested in 2007 at 14 stations where both trawls were deployed (Table 1$)$. Mean $( \pm$ SD) TL of fish differed significantly $(\mathrm{p}=0.0001)$ between the otter $(95 \pm$ $63 \mathrm{~mm})$ and beam trawls $(144 \pm 87 \mathrm{~mm})$ by Hotelling's T2 randomization test. Of the main fish species caught in 2007, the otter trawl often caught a higher proportion of small fish than any caught by the beam trawl (Fig. 4). We speculate that as the catch accumulated in the otter trawl, the head rope would become lower and the doors and foot rope would dig deeper into the sediments, perhaps selecting against larger fish and for smaller benthic fish compared with the beam trawl, which has a higher and more constant mouth opening and runners instead of doors. For instance, the TL of shorthorn sculpin Myoxocephalus scorpius caught by the otter trawl averaged ( \pm SD) $222 \pm 103 \mathrm{~mm}$ (range, 52 to $335 \mathrm{~mm}$ ), while those caught by the beam trawl averaged $301 \pm 46 \mathrm{~mm}$ (range, 230 to $380 \mathrm{~mm}$ ) (Table 1).

Perhaps because of this apparent tendency of the otter trawl to catch larger numbers of smaller fish, abundances of the 4 dominant fish species were 2.2 to 4.6 times higher in samples from the otter trawl than from the beam trawl (Table 1). Ratios of abundance in the otter trawl versus the beam trawl were 18.6 for Arctic cod Boreogadus saida and 14.1 for Arctic alligatorfish Ulcina olrikii. These extreme differences were amplified because these species were caught at only 1 of 14 stations by the beam trawl, resulting in low mean values in beam trawl abundance (see Table 1). Accord- 
Table 1. Mean $( \pm \mathrm{SD})$ dominant fish abundance and their ratios as collected by otter and beam trawls, along with the mean $( \pm$ SD) total length (TL) of fish collected during 2007 using both devices at 14 stations. Numbers in parentheses are sample size

\begin{tabular}{|llccrrr|}
\hline Common name & Scientific name & Abundance (no. fish km ${ }^{-2}$ ) & $\begin{array}{c}\text { Otter/beam } \\
\text { ratio }\end{array}$ & Fish TL (mm) \\
& & Beam & Otter & & Beam & Otter \\
\hline Arctic cod & Boreogadus saida & $148 \pm 600$ & $2748 \pm 2381$ & 18.6 & $182 \pm 0(1)$ & $90 \pm 30(50)$ \\
Bering flounder & Hippoglossoides robustus & $1173 \pm 1762$ & $2636 \pm 3172$ & 2.2 & $123 \pm 43(13)$ & $79 \pm 59(54)$ \\
Snailfish & Liparidae & $1288 \pm 2562$ & $4738 \pm 7655$ & 3.7 & $89 \pm 27(15)$ & $79 \pm 16(74)$ \\
Arctic alligatorfish & Ulcina olrikii & $113 \pm 457$ & $1589 \pm 2255$ & 14.1 & $71 \pm 0(1)$ & $60 \pm 8(19)$ \\
Arctic staghorn sculpin & Gymnocanthus tricuspis & $688 \pm 1875$ & $1857 \pm 4952$ & 2.7 & $98 \pm 17(6)$ & $87 \pm 18(15)$ \\
Shorthorn sculpin & Myoxocephalus scorpius & $428 \pm 1332$ & $1980 \pm 4084$ & 4.6 & $301 \pm 46(10)$ & $222 \pm 103(26)$ \\
\hline
\end{tabular}

ingly, we found that a greater number of fish were caught by the otter trawl than the beam trawl at the same stations in 2007.

\section{Groundfish spatial distribution}

In 2006 we collected 1034 fish representing at least 26 species (snailfish [Liparidae] were identified only to family level in both years), and 973 fish representing at
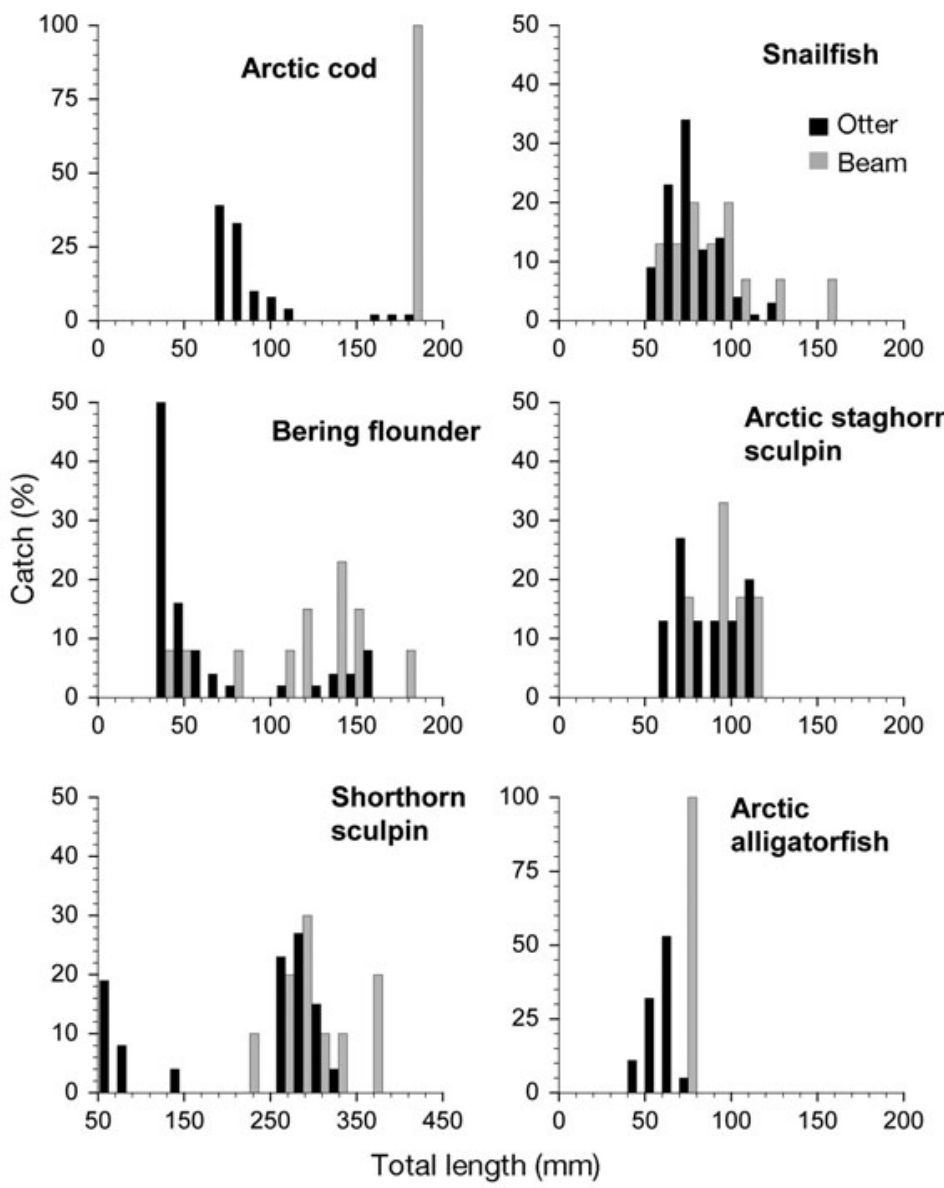

Fig. 4. Percent occurrence by total length group of the main fish species caught by beam (gray bars) and otter (black bars) trawls in 2007 least 17 species in 2007 (for further details see Cui 2009). A few unidentified species were also collected each year. When the otter trawl was used in 2006, most stations $(82 \%)$ had 2 to 6 species, no station had $>8$ species, and 3 stations ( $5 \%$ ) had no catch of fish. When the beam trawl was used in 2007, no station had $>6$ species, and 9 stations (14\%) had no catch of fish. In 2006, almost half of the stations had $>1000$ fish $\mathrm{km}^{-2}$ (Fig. S2 available as Supplementary Material at www.int-res.com/articles/suppl/m393p147_app.pdf). In $2007,75 \%$ of the stations had fish abundances of $>1000$ fish $\mathrm{km}^{-2}$ and about one third of the stations had $>5000$ fish $\mathrm{km}^{-2}$, including one station (DLN4) that had $>20000$ fish $\mathrm{km}^{-2}$ (Fig. S2). Fish species, except flatfishes, caught in the study area were small in size $(<220 \mathrm{~mm})$ compared with commercial fishery observations in the southern Bering Sea; the largest fish caught in both years were shorthorn sculpin (up to 430 $\mathrm{mm}$ ) (Fig. 5).

Arctic cod, Bering flounder Hippoglossoides robustus and snailfish generally had high abundances and high FO (FO >50\%) among stations in both years except that Arctic cod were caught at only $32 \%$ of stations in 2007 (see Table 2). Arctic cod had the highest abundance of all fish in 2006 with a FO of $75 \%$, whereas Bering flounder had the highest abundance in 2007 with a FO of $75 \%$. Shorthorn sculpin had the highest biomass in both years with low FO (8 to $11 \%$ ). Most fish species had higher abundance in 2007 than in 2006 (Table 2).

In both sampling years, there were consistently 2 species groups (Groups I and II) and 2 distinctive station groups (we term South and North, out of 3 station groups identified) determined from fish abundance data (Fig. 6a,b). Arctic cod, Bering flounder and snailfish were in a distinct species Group I and Arctic alligatorfish and Arctic staghorn sculpin Gymnocanthus tricuspis clustered in a species Group II. The stations sharing similar fish community 

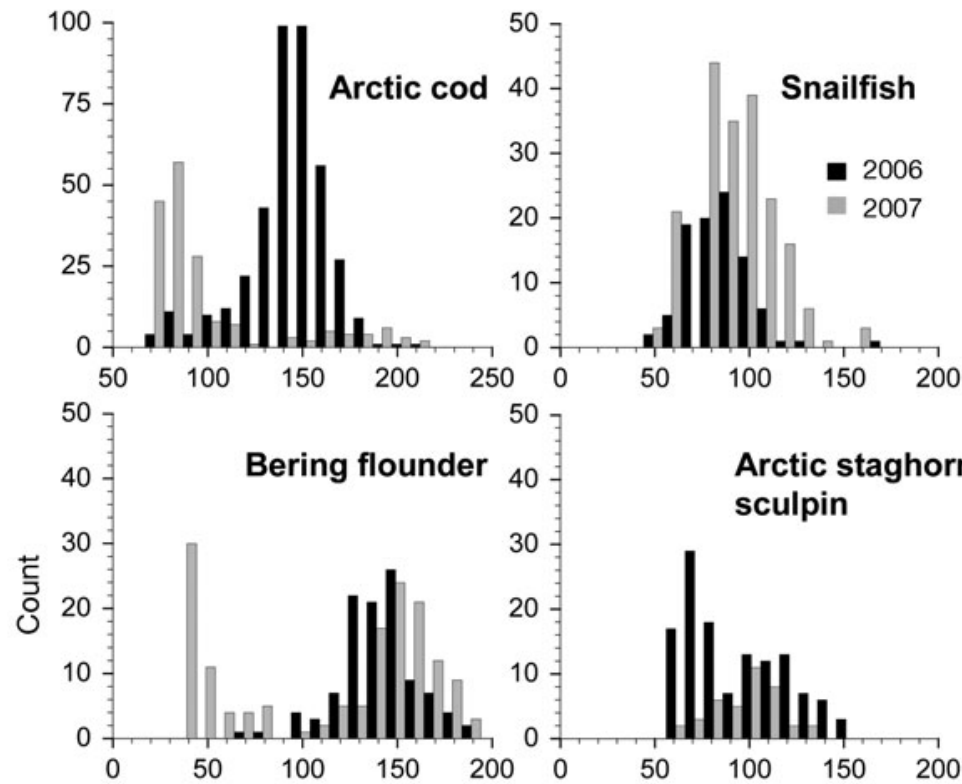

507
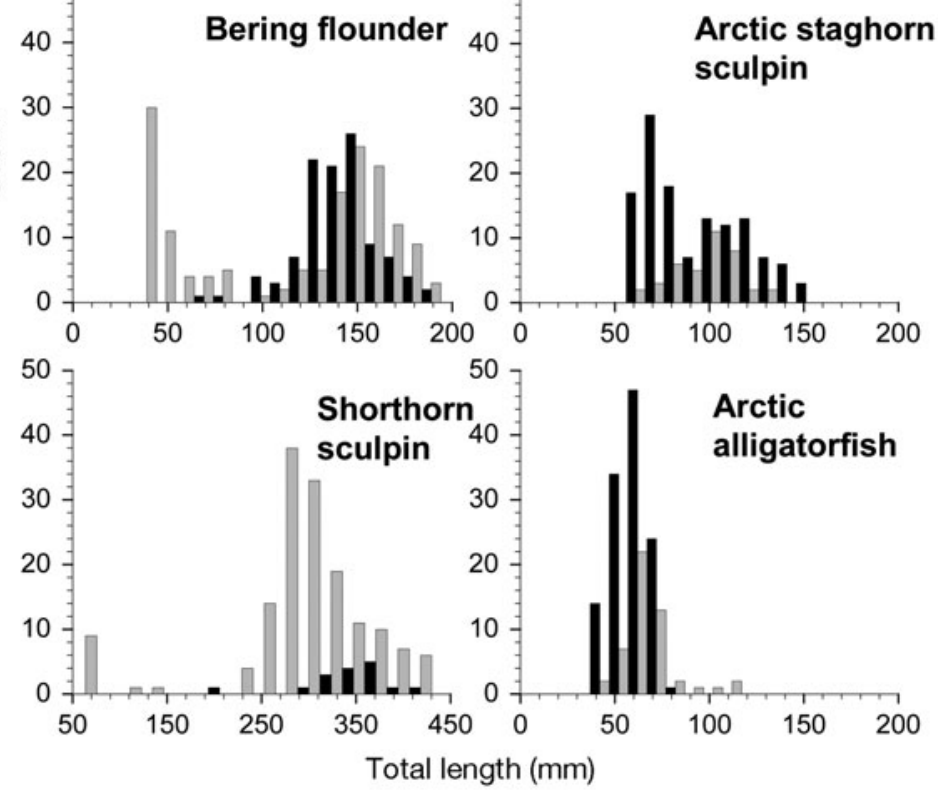

Fig. 5. Numbers of fish (count) by total length group of dominant fish species from all catches in 2006 (black bars) and 2007 (gray bars) structure were grouped into clusters and a third overlapping group we term Group O (Overlap). The station group South cluster was the largest and located mainly to the southwest and at a few stations north of SLI. This cluster group was typified by cooccurring species Group I, which included Arctic cod, Bering flounder and snailfish. In 2006, Arctic cod was most abundant, and the latter 2 species were most abundant in 2007. Station group North was located north of the island and was dominated by species Group II, Arctic alligatorfish and Arctic staghorn sculpin, and also high numbers of Arctic cod in 2006. In 2007, shorthorn sculpin occurred mostly in the North group. Station Group O overlapped spatially with station group South, and was dominated by high numbers of snailfish in 2006, and Arctic cod and snailfish in 2007. Hotelling's T2 randomization test showed a significant difference $(p<0.01)$ between station groups South and North in some fish species, but no significant difference ( $p>0.05$ ) for either South or North groups with Group $\mathrm{O}$ in either year. Arctic staghorn sculpin and Arctic alligatorfish were significantly (both $\mathrm{p}<0.001$ ) higher in abundance in station groups North than in South in 2006, and shorthorn sculpin was significantly $(p<0.001)$ higher in 2007.

Table 2. Groundfish frequency of occurrence (FO) and their mean abundance and CPUA in 2006 and 2007. Mean abundance from original otter trawl data in 2006 were adjusted to be comparable with data from the beam trawl in 2007 (Fig. 2). Species are only tabulated when FO was $>3 \%$ in either year

\begin{tabular}{|c|c|c|c|c|c|}
\hline \multirow{2}{*}{ Common name } & \multirow{2}{*}{ Scientific name } & \multicolumn{2}{|c|}{2006} & \multicolumn{2}{|c|}{2007} \\
\hline & & $\begin{array}{l}\text { Frequency of } \\
\text { occurrence }(\%)\end{array}$ & $\begin{array}{l}\text { Abundance } \\
\left(\text { no. fish } \mathrm{km}^{-2} \text { ) }\right.\end{array}$ & $\begin{array}{l}\text { Frequency of } \\
\text { occurrence (\%) }\end{array}$ & $\begin{array}{c}\text { Abundance } \\
\left(\text { no. fish } \mathrm{km}^{-2} \text { ) }\right.\end{array}$ \\
\hline Arctic cod & Boreogadus saida & 75 & 509 & 32 & 316 \\
\hline Bering flounder & Hippoglossoides robustus & 56 & 146 & 75 & 1207 \\
\hline Snailfish & Liparidae & 56 & 52 & 51 & 1061 \\
\hline Walleye pollock & Theragra chalcogramma & 42 & 34 & 3 & 14 \\
\hline Arctic alligatorfish & Ulcina olrikii & 27 & 88 & 13 & 289 \\
\hline Arctic staghorn sculpin & Gymnocanthus tricuspis & 17 & 118 & 8 & 189 \\
\hline Veteran poacher & Podothecus veternus & 15 & 4 & 8 & 67 \\
\hline Stout eelblenny & Anisarchus medius & 10 & 12 & 5 & 25 \\
\hline Shorthorn sculpin & Myoxocephalus scorpius & 8 & 8 & 11 & 463 \\
\hline Yellowfin sole & Limanda aspera & 8 & 1 & 5 & 31 \\
\hline Capelin & Mallotus villosus & 8 & 2 & - & - \\
\hline Alligatorfish & Aspidophoroides monopterygius & 8 & 1 & 2 & 10 \\
\hline Pacific herring & Clupea pallasii & 5 & 3 & 2 & 5 \\
\hline Sakhalin sole & Limanda sakhalinensis & 3 & 0 & 3 & 14 \\
\hline Wattled eelpout & Lycodes palearis & 2 & 4 & 5 & 73 \\
\hline Alaska plaice & Pleuronectes quadrituberculatus & 10 & 0 & 3 & 19 \\
\hline Pacific cod & Gadus macrocephalus & - & - & 3 & 10 \\
\hline Spatulate sculpin & Icelus spatula & - & - & 3 & 6 \\
\hline
\end{tabular}



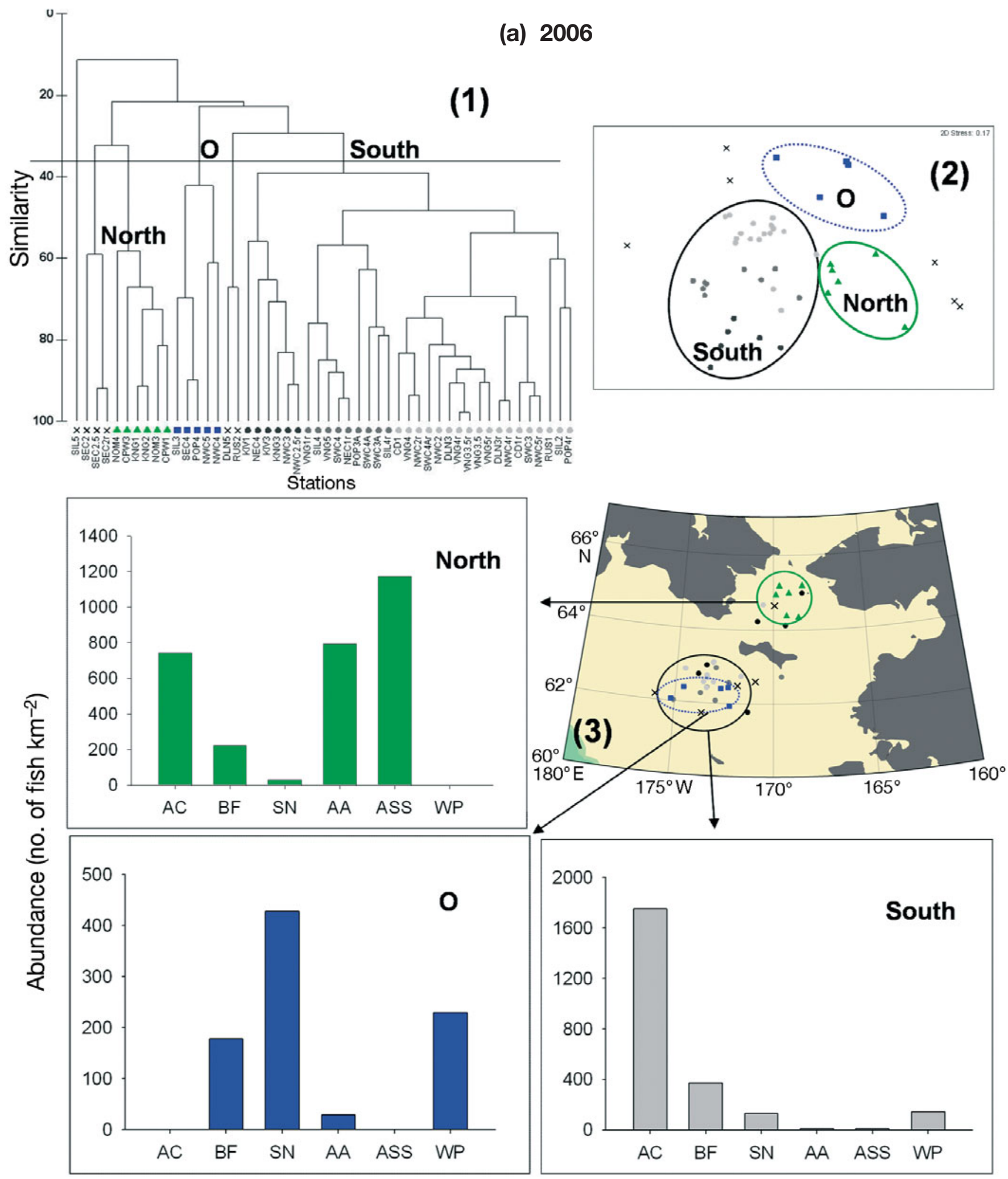

Fish species

Fig. 6. (a) 2006 and (b) 2007. (1) Dendrogram separating 3 station groups (North, O, South) by cluster analysis based on fish abundance in each year. Horizontal line: group generation at a specified resemblance. (2) Multidimensional scaling (MDS) diagram of station groups. (3) Spatial distribution and abundance of the main fish species of station groups using cluster analysis of fish abundance. Data from the otter trawl in 2006 were adjusted to be comparable with data from the beam trawl in 2007 (see Fig. 2). Group South: circles filled with black to light gray; Group North: green filled triangles; Group O: blue filled squares; outlier group: cross. AC: Arctic cod; BF: Bering flounder; SN: snailfish; AA: Arctic alligatorfish; ASS: Arctic staghorn sculpin; WP: walleye pollock; 

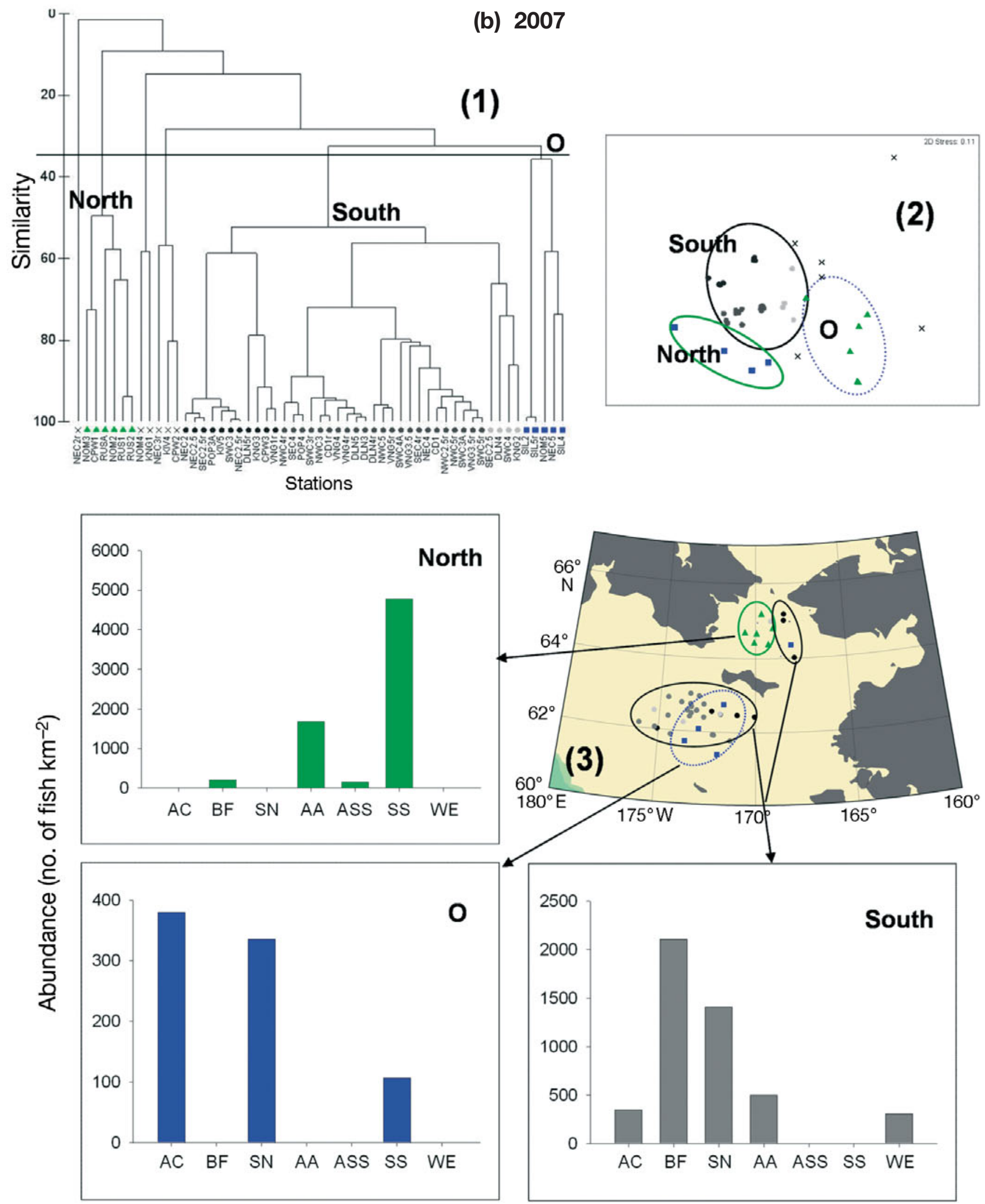

Fish species

Fig. 6 (continued) 
Table 3. Dominant (+) and absent (-) fish species in each station group and significant environmental factors influencing fish abundance. Environmental factors shown are those that are significantly different $(p<0.01)$ between groups ( $p<0.05$ for TON in 2007); nonsignificant $(p>0.05)$ values are omitted. Significance test was Hotelling's T2 randomization test. $\mathrm{n}=$ sample size in each group, T: bottom water (BW) temperature; BW chl a: BW chlorophyll $a$; Int chl $a$ : integrated water column chlorophyll $a_{\text {; }}$ Grain size: sediment grain size; TOC: total organic carbon in surface sediments; TON: total organic nitrogen in surface sediments

\begin{tabular}{|c|c|c|c|c|}
\hline \multirow[b]{2}{*}{ Station group: } & \multicolumn{2}{|c|}{$2006-$} & \multicolumn{2}{|c|}{$-2007 \longleftarrow$} \\
\hline & South $(\mathrm{n}=30)$ & North $(\mathrm{n}=6)$ & South $(n=38)$ & North $(n=6)$ \\
\hline \multicolumn{5}{|l|}{ Fish species } \\
\hline Arctic cod & + & + & + & - \\
\hline Bering flounder & + & $--^{\mathrm{a}}$ & + & $-{ }^{\mathrm{a}}$ \\
\hline Snailfish & + & $-^{\mathrm{a}}$ & + & - \\
\hline Arctic alligatorfish & $-^{\mathrm{a}}$ & + & $-^{\mathrm{a}}$ & + \\
\hline Arctic staghorn sculpin & - & + & - & $-{ }^{\mathrm{a}}$ \\
\hline Shorthorn sculpin & $--^{\mathrm{a}}$ & - & - & + \\
\hline \multicolumn{5}{|c|}{ Environmental factors (mean \pm SD) } \\
\hline $\mathrm{T}\left({ }^{\circ} \mathrm{C}\right)$ & $-1.6 \pm 0.2$ & $-1.4 \pm 0.2$ & $-1.4 \pm 0.6$ & $-0.0 \pm 0.4$ \\
\hline Depth (m) & $64 \pm 12$ & $45 \pm 4$ & $65 \pm 14$ & $45 \pm 3$ \\
\hline BW $\operatorname{chl} a\left(\mathrm{mg} \mathrm{m}^{-3}\right)$ & $6.5 \pm 4.5$ & $18.0 \pm 5.1$ & - & - \\
\hline Int chl $a\left(\mathrm{mg} \mathrm{m}^{-2}\right)$ & $465 \pm 216$ & $780 \pm 160$ & - & - \\
\hline Grain size (phi) & $4.7 \pm 0.6$ & $3.2 \pm 0.4$ & $4.6 \pm 0.7$ & $3.3 \pm 0.8$ \\
\hline TOC (\%) & $1.0 \pm 0.5$ & $0.3 \pm 0.1$ & $1.0 \pm 0.5$ & $0.4 \pm 0.2$ \\
\hline TON (\%) & $0.2 \pm 0.1$ & $0.1 \pm 0.0$ & $0.2 \pm 0.1$ & $0.1 \pm 0.0$ \\
\hline
\end{tabular}

water column chl a values, finer sediment grain sizes and higher sediment total organic carbon and nitrogen content than group North ( $\mathrm{p}<0.01$, Table 3$)$.

The BIO-ENV procedure indicated that there were high correlations $(\rho>0.95$, collinearity) between silica and phosphate and between TOC and TON in 2006. Therefore, we excluded some parameters where they were colinear because of confounding effects on the analysis (Clarke \& Warwick 2001). On this basis we retained silica and TOC in the analysis structure and phosphate and TON were dropped from the BIO-ENV procedure in 2006. The result showed that 4 -variable subsets had better correlations ( $\rho=0.46$ and 0.45 ) than any other best single abiotic variable or 2- and 3-way variable combinations in 2006 (Table 4). Adding additional variables above these 4 only marginally improved correlations in 2006. We concluded that the 4 optimal parameters in 2006 were bottom water nitrate + nitrite, bottom water chl a (or integrated water column $\mathrm{chl}$ a), sediment grain size and sediment $\mathrm{C} / \mathrm{N}$, which were

\section{Relationship with environmental factors}

The randomization procedure of Hotelling's T2 test revealed that environmental variables were not significantly different between station groups South and $\mathrm{O}(\mathrm{p}>0.05)$, whereas environmental variables were significantly different between station groups South and North ( $p<0.05$ in 2006, $p=0.001$ in 2007). Station group South had lower bottom water temperatures, was deeper, had lower bottom water and integrated best correlated with fish distributions in 2006. In 2007 the correlation $(\rho=0.51)$ was slightly better for a best 2-variable combination (bottom water temperature and sediment grain size) than for the best single abiotic variable (bottom water temperature, $\rho=0.50$ ) with little correlative improvement with the addition of third and higher variables (Table 4). Therefore, bottom water temperature and sediment grain size were identified as the environmental variables that best explained fish distribution in 2007.

Table 4. The combination of environmental variables that best explains groundfish community structures in 2006 and 2007 . Up to 2 possibilities are shown, each with the highest Spearman correlation $(\rho)(p<0.01$; null hypothesis: $\rho=0)$ with no more than 5 variables included. T: bottom water (BW) temperature; Si: $\mathrm{BW}$ silica; $\mathrm{N}$ : $\mathrm{BW}$ nitrite + nitrate; $\mathrm{NH}_{4}$ : $\mathrm{BW}$ ammonium; $\mathrm{BW}$ chl a: $\mathrm{BW}$

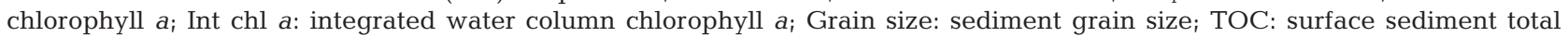
organic carbon; $\mathrm{C} / \mathrm{N}$ : surface sediment total organic carbon and nitrogen ratio; optimal combinations are in bold and italic text

\begin{tabular}{|c|c|c|c|c|}
\hline No. & 2006 & $\rho$ & 2007 & $\rho$ \\
\hline 1 & Grain size & 0.290 & $\begin{array}{l}T_{;} \\
\text {Grain size }\end{array}$ & $\begin{array}{l}0.496 \\
0.400\end{array}$ \\
\hline 2 & $\begin{array}{l}\text { Int chl } a \text {, Grain size; } \\
\text { Int chl } a \text {, TOC }\end{array}$ & $\begin{array}{l}0.365 \\
0.364\end{array}$ & $\begin{array}{l}\text { T, Grain size; } \\
\mathrm{T}, \mathrm{Si}\end{array}$ & $\begin{array}{l}\mathbf{0 . 5 0 8} \\
0.470\end{array}$ \\
\hline 3 & $\begin{array}{l}\text { Int chl } a \text {, Grain size, } \mathrm{C} / \mathrm{N}_{i} \\
\text { BW chl } a \text {, Grain size, C/N }\end{array}$ & $\begin{array}{l}0.420 \\
0.417\end{array}$ & $\begin{array}{l}\mathrm{T}, \mathrm{Si} \text {, Grain size; } \\
\mathrm{T}, \mathrm{NH}_{4}, \text { Grain size }\end{array}$ & $\begin{array}{l}0.509 \\
0.492\end{array}$ \\
\hline 4 & $\begin{array}{l}N, B W \text { chl a, Grain size, } C / N ; \\
N, \text { Int chl a, Grain size, } C / N\end{array}$ & $\begin{array}{l}0.457 \\
0.447\end{array}$ & $\begin{array}{l}\mathrm{T}, \mathrm{Si}, \text { Grain size, } \mathrm{TOC}_{i} \\
\mathrm{~T}, \mathrm{Si}, \mathrm{NH}_{4}, \text { Grain size }\end{array}$ & $\begin{array}{l}0.503 \\
0.499\end{array}$ \\
\hline 5 & $\begin{array}{l}\text { Depth, N, BW chl } a \text {, Grain size, C/N; } \\
\text { Depth, N, Int chl } a \text {, Grain size, C/N }\end{array}$ & $\begin{array}{l}0.468 \\
0.459\end{array}$ & $\begin{array}{l}\text { T, Si, } \mathrm{NH}_{4} \text {, Grain size, TOC; } \\
\text { T, Si, N, BW chl a, Grain size }\end{array}$ & $\begin{array}{l}0.496 \\
0.494\end{array}$ \\
\hline
\end{tabular}




\section{DISCUSSION}

\section{Water mass and fish abundance}

The results indicate 2 distinct spatial distributions of benthic fish communities in the northern Bering Sea. One group, located south of SLI, was dominated by Arctic cod, Bering flounder and snailfish. Another group, located north of SLI, was dominated by Arctic alligatorfish and Arctic staghorn sculpin or shorthorn sculpin. Bottom water temperatures were lower south of SLI and higher north of SLI. Coincidently, sediment grain size was characterized by finer silt/clay sediments south of SLI compared with coarser sandy sediments north of SLI, which is indicative of the slower and faster current regimes in the different regions, respectively.

When evaluating benthic fish populations south of SLI they were more abundant in the western side of the St. Lawrence Island Polynya (SLIP) region where there is a higher proportion of saline, nutrient-rich Anadyr water versus the eastern side of the SLIP region, which is known to be more influenced by fresher, nutrient-depleted Bering Shelf water and Alaska Coastal water in the spring. Another difference is the finer grain size of sediments on the western side of the southern SLI system compared with relatively more coarse sediments on the eastern side of the study area. Thus, the associated variability in habitat and environmental conditions suggests that these different habitats support different benthic fish assemblages, and the variation in fish species distribution is controlled by hydrographic features and sediment type (associated with current speed).

\section{Difference in fish abundance and size structure in both years}

Arctic cod was widely distributed with a FO of $75 \%$ by otter trawl in 2006 and $32 \%$ by beam trawl in 2007 , which is consistent with previous work in this area (FO of $56 \%$ by otter trawl, Lowry \& Frost 1981). Arctic cod had a much lower FO and abundance in 2007 than in 2006, which might be related to lower seasonal ice coverage in 2007 at the time of sampling. The overall distribution of Arctic cod is associated with ice cover, which the fish use for feeding and protection from predators (Andriyashev 1964, Lønne \& Gulliksen 1989, Crawford \& Jorgenson 1993, Wyllie-Echeverria \& Wooster 1998). This probably explains the higher abundance of Arctic cod in the northeastern Chukchi and western Beaufort seas where there is more ice cover than in the northern Bering Sea (Lowry \& Frost 1981).
We found that beam trawls tend to catch larger fish than do otter trawls; however, we collected a higher proportion of small size class Arctic cod, Bering flounder and shorthorn sculpin by beam trawl in 2007 than in 2006 using an otter trawl (Fig. 5). There was no major difference in snailfish length between the $2 \mathrm{yr}$, while Arctic staghorn sculpin and Arctic alligatorfish had higher proportions of smaller fish in 2006 than in 2007. The small size class peaks in Fig. 5 may represent first-year recruits for some species. The mean total length we observed for Arctic cod $(\sim 80 \mathrm{~mm})$ is similar to other observations in the Bering, Chukchi and Beaufort seas (Lowry \& Frost 1981, Craig et al. 1982, Gillispie et al. 1997). Previous studies suggest that warmer waters and less ice cover may increase survival and growth of Arctic cod (Gillispie et al. 1997, Fortier et al. 2006). In addition, Arctic cod populations can respond to environmental conditions within a year, while other fish such as walleye pollock Theragra chalcogramma respond over time frames of several years (Wyllie-Echeverria \& Wooster 1998).

It is possible that warmer temperature and the reduced ice extent in 2007 increased young-of-theyear fish abundance in some species. Bering flounder, for example, move northward with higher bottom water temperature (Mueter \& Litzow 2008, Spencer 2008). In the present study, Bering flounder was more abundant (from 1200 to 6000 fish $\mathrm{km}^{-2}$ ) close to Bering Strait, where bottom water temperatures were much higher in 2007 relative to 2006. Shorthorn sculpin, which were dominant north of SLI, increased in 2007 coincidently with the higher bottom water temperature in the North station group.

Responses to climate factors vary widely among fish species (Skud 1982). In the present study, groundfish species that showed similar proportional changes in fish size categories between the $2 \mathrm{yr}$, also have similar general distribution patterns in the sub-Arctic or Arctic seas. Generally, Arctic cod, Bering flounder and shorthorn sculpin are distributed throughout the Bering Sea and into the Arctic Ocean. Snailfish occur only south of Bering Strait with the exception of a few species. Arctic staghorn sculpin and Arctic alligatorfish are distributed from north of SLI to the Arctic Ocean (Mecklenburg et al. 2002; Fig. S2). Different thermal tolerances of 'arctic' and 'subarctic' community groups are likely to lead to differing responses to the increased bottom water temperature (Mueter \& Litzow 2008). However, our data do not show clear evidence of a 1 yr response to a shift in temperature. Further work is needed to evaluate whether fish communities respond directly to changing seawater temperatures, or whether the differences observed result only from asynchronous interannual variations among species. 
Reproductive strategies might also affect the response of fish size structure to climate change. For example, sculpins lay adhesive eggs in nests and many provide parental care for eggs, while other groundfish species do not (Eschmeyer et al. 1983). This reproductive strategy of sculpins might make them more sensitive to changes in benthic habitats than other groundfish species that produce pelagic eggs (Reuter \& TenBrink 2008).

\section{Effects of grain size and temperature}

We found that sediment grain size had a significant influence on groundfish distributions in both years, which is consistent with a previous study by Scott (1982). McConnaughey \& Smith (2000) concluded that strong preferences among sediment textures by flatfish results from differences in prey availability. Arctic staghorn sculpin were absent in muddy or clay sediments, and burrowed in sandy-muddy sediments (Andriyashev 1964, Smith et al. 1997). The distributions and abundances of benthic invertebrates in this region are highly correlated with sediment type (Grebmeier et al. 1989, Grebmeier \& Barry 2007). Therefore, habitat factor (such as sediment grain size) may directly or indirectly influence fish assemblages.

In 2006 sampling occurred earlier in the season ( 7 May to 5 June) than in 2007 (16 May to 18 June), and 2006 also had higher sea ice cover, which influences the development of the spring bloom. We found that the concentration of chl $a$ in the bottom water (and water column) differed between station groups North and South in 2006, which was probably due to the different timing of the spring bloom and settling of phytoplankton to the benthos between the 2 areas. In 2007, the main bloom in both regions had progressed further as the ice had retreated earlier and we also arrived $\sim 10$ d later than we did in 2006; thus, we observed no difference in chl a concentrations in the bottom water (and water column) between station groups North and South of the island. We suggest that during the colder year (2006), bottom water (and water column) chl a might have affected benthic fish distributions indirectly by affecting the total amount of phytodetritus reaching the benthos, thus influencing the distribution and abundance of benthic prey to fish. In addition, in 2006 there was less of a temperature difference between the southern and northern areas; thus, temperature was not a significant variable influencing fish population structure. With the later station occupations in 2007 when ice cover was reduced and bottom seawater was warmer to the north of SLI, temperature had a greater influence on fish community structure, since the region south of SLI still had cold bottom water temperatures due to the presence of the cold pool.

Reorganization of fish communities can be triggered by climate regime shifts, although other complex factors (such as availability of prey or nutrients) can also be important (Anderson \& Piatt 1999, Litzow et al. 2006). In the North Sea, a number of fish species have shifted northward in response to increases in sea water temperature (Perry et al. 2005). Similarly, in the Bering Sea walleye pollock were distributed farther north during years with warm sea surface temperatures (SSTs) than in years with cool SSTs (Helle et al. 2007). Our results suggest that groundfish community distribution and abundance are also affected by environmental factors such as bottom water temperature, sediment grain size and water column nutrients via effects on primary production. If recently observed warming trends continue in the Bering Sea (e.g. Overland \& Stabeno 2004, Grebmeier et al. 2006), it might change the hydrodynamics and indirectly affect sedimentation (or sediment grain size, Dolch \& Hass 2008), which is, in turn, another influence on groundfish abundance and distribution in the northern Bering Sea. The fish assemblages and their relations to environmental factors identified in the present study were based on only 2 spring seasons and available measurements of 14 environmental factors. Thus, our data are limited in the extent that they address seasonal changes or longerterm trends among years. Despite this, our results may also provide important information for developing effective ecosystem management of fisheries in the northern Bering Sea. For example, if current climate warming trends continue, modeling of future fish populations will become increasingly critical.

Acknowledgements. We thank C. Mecklenburg, who graciously helped identify some of the fish specimens. We also thank the marine science technicians from the USCGC 'Healy' in 2006 and 2007, S. H. Lee, M. Blikshteyn and others who assisted with sample collections at sea. We thank 4 anonymous reviewers for constructive suggestions that improved an earlier version of the manuscript. Support for this research was provided by the US National Science Foundation through a grant to J. R. Lovvorn, J. M. Grebmeier and L. W. Cooper (OPP-ARC-0454454) as well as support provided to X. Cui by the state of Tennessee through the University of Tennessee, Knoxville.

\section{LITERATURE CITED}

Anderson PJ, Piatt JF (1999) Community reorganization in the Gulf of Alaska following ocean climate regime shift. Mar Ecol Prog Ser 189:117-123

Andriyashev AP (1964) Fishes of the northern seas of the USSR. Israel Program for Scientific Translations, Jerusalem

Aydin K, Mueter F (2007) The Bering Sea-a dynamic food web perspective. Deep-Sea Res II 54:2501-2525

Bluhm BA, Gradinger R (2008) Regional variability in food 
availability for Arctic marine mammals. Ecol Appl 18: S77-S96

Brodeur RD, Wilson MT, Walters GE, Melnikov IV (1999) Forage fishes in the Bering Sea: distribution, species associations, and biomass trends. In: Loughlin TR, Ohtani K (eds) Dynamics of the Bering Sea. University of Alaska Sea Grant, Fairbanks, AK, p 509-536

Clarke KR, Warwick RM (2001) Change in marine communities: an approach to statistical analysis and interpretation, 2nd edn. PRIMER-E, Plymouth, www.primer-e.com/

> Clement JL, Cooper LW, Grebmeier JM (2004) Late winter water column and sea ice conditions in the northern Bering Sea. J Geophys Res 109(C3):C03022

- Clement JL, Maslowski W, Cooper LW, Grebmeier JM, Walczowski W (2005) Ocean circulation and exchanges through the northern Bering Sea-1979-2001 model results. Deep-Sea Res II 52:3509-3540

Cooper LW, Grebmeier GM, Larsen IL, Egorov VG, Theodorakis C, Kelly HK, Lovvorn JR (2002) Seasonal variation in sedimentation of organic materials in the St. Lawrence Island polynya region, Bering Sea. Mar Ecol Prog Ser 226: 13-26

> Craig PC, Griffiths WB, Haldorson L, McElderry H (1982) Ecology studies of Arctic cod (Boreogadus saida) in Beaufort Sea coastal waters, Alaska. Can J Fish Aquat Sci 39:395-406

Crawford RE, Jorgenson JK (1993) Schooling behaviour of arctic cod, Boreogadus saida, in relation to drifting pack ice. Environ Biol Fishes 36:345-357

Cui X (2009) Climate-driven impacts of groundfish on food webs in the northern Bering Sea. PhD dissertation, University of Tennessee

> Danielson S, Aagaard K, Weingartner T, Martin S, Winsor P, Gawarkiewicz G, Quadfasel D (2006) The St. Lawrence polynya and the Bering shelf circulation: new observations and a model comparison. J Geophys Res 111:C09023

Dolch T, Hass HC (2008) Long-term changes of intertidal and subtidal sediment compositions in a tidal basin in the northern Wadden Sea (SE North Sea). Helgol Mar Res 62: $3-11$

Eschmeyer WN, Herald ES, Hammann H (1983) A field guide to Pacific coast fishes of North America. Houghton Mifflin, Boston, MA

Fetterer F, Knowles K, Meier W, Savoie M (2008) Sea ice index. National Snow and Ice Data Center, Boulder, CO

> Fortier L, Sirois P, Michaud J, Barber D (2006) Survival of Arctic cod larvae (Boreogadus saida) in relation to sea ice and temperature in the Northeast Water Polynya (Greenland Sea). Can J Fish Aquat Sci 63:1608-1616

Gauch HG Jr (1982) Multivariate analysis in community ecology. Cambridge University Press, New York

Gillispie JG, Smith RL, Barbour E, Barber WE (1997) Distribution, abundance, and growth of arctic cod in the northeastern Chukchi Sea. Am Fish Soc Symp 19:81-89

Grebmeier JM, Barry JP (2007) Benthic processes in polynyas. In: Smith WO Jr, Barber DG (eds) Polynyas: windows to the world. Elsevier Oceanography Series 74, Amsterdam, p 363-390

Grebmeier JM, Cooper LW (1995) Influence of the St. Lawrence Island polynya upon the Bering Sea benthos. J Geophys Res 100:4439-4460

Grebmeier JM, Feder HM, McRoy CP (1989) Pelagic-benthic coupling on the shelf of the northern Bering and Chukchi Seas. II. Benthic community structure. Mar Ecol Prog Ser 51:253-268

Grebmeier JM, Overland JE, Moore SE, Farley EV and others (2006) A major ecosystem shift in the northern Bering Sea. Science 311:1461-1464
Helle J, Farley E, Murphy J, Feldmann A and others (2007) The Bering-Aleutian salmon international survey (BASIS). AFSC Quarterly Report (January-February-March 2007) www.afsc.noaa.gov/Quarterly/jfm2007/jfm07feat.pdf

Hintze J (2009) Number cruncher statistical systems (NCSS, version 2007). Kaysville, UT, www.ncss.com

> Litzow MA, Bailey KM, Prahl FG, Heintz R (2006) Climate regime shifts and reorganization of fish communities: the essential fatty acid limitation hypothesis. Mar Ecol Prog Ser 315:1-11

> Lønne OJ, Gulliksen B (1989) Size, age and diet of Polar cod, Boreogadus saida (Lepechin 1773), in ice covered waters. Polar Biol 9:187-191

Loughlin TR, Sukhanova IN, Sinclair EH, Ferrero RC (1999) Summary of biology and ecosystem dynamics in the Bering Sea. In: Loughlin TR, Ohtani K (eds) Dynamics of the Bering Sea. University of Alaska Sea Grant, Fairbanks, AK, p 387-407

Lowry LF, Frost KJ (1981) Distribution, growth, and the foods of Arctic cod (Boreogadus saida) in the Bering, Chukchi, and Beaufort Seas. Can Field Nat 95:186-191

$>$ McConnaughey RA, Smith KR (2000) Association between flatfish abundance and surficial sediments in the eastern Bering Sea. Can J Fish Aquat Sci 57:2410-2419

Mecklenburg CW, Mecklenburg TA, Thorsteinson LK (2002) Fishes of Alaska. American Fisheries Society, Bethesda, MD

> Mueter FJ, Litzow MA (2008) Sea ice retreat alters the biogeography of the Bering Sea continental shelf. Ecol Appl 18:309-320

Mueter FJ, Norcross BL (2002) Spatial and temporal patterns in the demersal fish community on the shelf and upper slope regions of the Gulf of Alaska. Fish Bull 100: $559-581$

Nihoul JCJ, Adam P, Brasseur P, Deleersnijder E, Djenidi S, Haus J (1993) Three-dimensional general circulation model of the Northern Bering Sea's summer ecohydrodynamics. Cont Shelf Res 13:509-542

> Overland JE, Stabeno PJ (2004) Is the climate of the Bering Sea warming and affecting the ecosystem? Eos Trans AGU 85, p 309-312

Perry AL, Low PJ, Ellis JR, Reynolds JD (2005) Climate change and distribution shifts in marine fishes. Science 308:1912-1915

Pirtle-Levy R (2006) A shelf-to-basin examination of food supply for arctic benthic macrofauna and the potential biases of sampling methodology. MS thesis, University of Tennessee

Reuter RF, TenBrink TT (2008) Assessment of sculpin stocks in the Bering Sea/Aleutian Islands. In: The plan team for the groundfish fisheries of the Bering Sea and Aleutian Islands. Stock assessment and fishery evaluation report for the groundfish resources of the Bering Sea/Aleutian Islands regions. North Pacific Fishery Management Council, Anchorage, AK, p 1409-1448, www.afsc.noaa.gov/ refm/docs/2008/BSAIsculpin.pdf

Schlitzer R (2003) Ocean data view (ODV, version 1.4), www.awi-bremerhaven.de/GEO/ODV

Scott JS (1982) Selection of bottom type by groundfishes of the Scotian Shelf. Can J Fish Aquat Sci 39:943-947

Serreze MC, Holland MM, Stroeve J (2007) Perspectives on the Arctic's shrinking sea-ice cover. Science 315: 1533-1536

> Skud BE (1982) Dominance in fishes: the relation between environment and abundance. Science 216:144-149

Smith RL, Vallarino M, Barbour E, Fitzpatrick E, Barber WE (1997) Population biology of the Bering flounder in the 
northeastern Chukchi Sea. Am Fish Soc Symp 19:127-132

Spencer PD (2008) Density-indepdendent and densitydependent factors affecting temporal changes in spatial distributions of eastern Bering Sea flatfish. Fish Oceanogr 17:396-410

Springer AM, McRoy CP, Flint MV (1996) The Bering Sea Green Belt: shelf-edge processes and ecosystem production. Fish Oceanogr 5:205-223

Editorial responsibility: Konstantinos Stergiou, Thessaloniki, Greece
Walsh JJ, McRoy CP, Coachman LK, Goering JJ and others (1989) Carbon and nitrogen cycling within the Bering/ Chukchi Seas: source regions for organic matter effecting AOU demands of the Arctic Ocean. Prog Oceanogr 22: 277-359

Wyllie-Echeverria T, Wooster WS (1998) Year-to-year variations in Bering Sea ice cover and some consequences for fish distributions. Fish Oceanogr 7:159-170

Submitted: December 26, 2008; Accepted: August 17, 2009 Proofs received from author(s): October 19, 2009 